\title{
VERSITA
}

Acta Veterinaria-Beograd 2014, 64 (1), 105-114

UDK: 636.4.09:[616.993-085.371

DOI: $10.2478 /$ acve-2014-0011

Research article

\section{INFLUENCE OF BETA-GLUCAN AND VACCINATION AGAINST LAWSONIA INTRACELLULARIS ON SELECTED IMMUNE INDICES IN WEANED PIGLETS}

\author{
KOVAČOCYOVÁ Katarína ${ }^{1 *}$, REICHEL Peter ${ }^{1}$, SEIDEL Herbert ${ }^{1}$, \\ BRENESSELOVÁ Martina², KÓSA Balász ${ }^{1}$
}

${ }^{1}$ Clinical Department for Swine; ${ }^{2}$ Department of Food Hygiene and Technology University of Veterinary Medicine and Pharmacy in Košice Komenského 73, 04181 Košice, The Slovak Republic

(Received 16 January 2014; Accepted 12 February 2014)

The aim of this paper was to study the immunostimulating effects of feed additive
containing beta-glucan given to pregnant sows and consecutive specific immuno-
modulation by vaccination of their suckling piglets. Thirty-five suckling piglets from
the control and experimental group of sows were divided into four groups. Selected
blood indices of immune profile (TIg, IMA, SI), specific antibodies against Lansonia
intracellularis formed in the blood serum of suckling piglets after vaccination, as well as
production indices were observed. In all the groups, birth body weights were similar.
After weaning, average daily weight gains were significantly higher ( $\mathrm{p}<0.05$ ) in the
group of vaccinated suckling piglets, as well as in suckling piglets from experimental
sows. The same trend was recorded in average TIg values. Significant effects ( $<<0.01$ )
of beta-glucan and vaccination were observed in the changes of the index of metabolic
activity of phagocytes (IMA) and less markedly in the index of stimulation activity
of lymphocytes (SI). The least favorable results were observed in the group without
both vaccination and beta-glucan. The effect of vaccination was manifested by ELISA
estimation of specific antibodies (PI), when in both non-vaccinated groups (A and D)
we observed minimum antibodies levels compared with vaccinated groups (B and C),
which showed a high positivity without significant differences between the beta-glucan
stimulated (C) and the non-stimulated group (B). These results suggest that beta-glucan
given to sows and consecutive vaccination of suckling piglets can stimulate their non
specific and specific immunity.

Key words: beta-glucan, Lawsonia intracellularis, immunostimulation, piglets

\section{INTRODUCTION}

Lawsonia intracellularis belongs to common intestinal infections with serious economic impacts because of reduced weight gain and feed conversion. This disease has a worldwide distribution and occurs in all pig-raising regions and in all pig farm management systems [1]. In present Europe, there are $34-67 \%$ of swine and $88-100 \%$ of rearings infected with Lawsonia intracellularis and following the latest evidence from 2011, the

\footnotetext{
*Corresponding author: e-mail: Katarina.Kovacocyova@student.uvlf.sk
} 
prevalence of this disease is $12-50 \%$ respectively and in Slovakia is 63\% [2]. Lawsonia intracellularis, belonging to family of Desulfovibrionaceae, is an obligate intra-cellular bacterium multiplying in cells of the intestinal epithelium. Outside the gastrointestinal tract, the microbe has also been demonstrated in the tonsils and mesenterial lymph nodes, but these appear to be secondary sites [3-5]. Proliferative enteropathy caused by $L$. intracellularis is divided into four forms based on morphological properties: proliferative hemorrhagic enteropathy (PHE), porcine intestinal adenomatosis (PIA), necrotic enteritis (NE) and regional ileitis (RI). The terms acute (PHE) and chronic (PIA, NE or RI) are preferred for use. The acute form of the disease is manifested as intestinal hemorrhage with fever, the chronic as diarrhea, decreased feed consumption and reduced weight gain [6,7]. In prevention of infections on pig farms, various approaches to medication are possible, depending on the age of pigs involved. The common practice was continuous medication of feedstuffs with antibiotics. According to a ban against microbial antibiotic use, one of the possible ways is vaccination against Lawsonia intracellularis. The vaccination stimulates innate danger signals by replication and amplification of antigen mass and induces the best humoral and cellular response $[7,8]$. The vaccination is efficient in controlling PPE (porcine proliferative enteropathy) and it increases the production indices in infected herds [9]. Infection usually occurs a few weeks after weaning, presumably when maternal antibodies fade. It is important to time the vaccination so that animals achieve immunity before exposure to the agent [10].

It is well known that beta glucans occur naturally in various sources; however, mostly they are obtained from mushroom cell walls. Among the most studied mushrooms $\beta$-glucans are: lentinan from Lentinus edodes, grifolan from Grifola frondosa, schizophyllan from Schizophyllum commune, and pleuran from Pleurotus ostreatus [11]. Beta-glucans are polysaccharides of D-glucose monomers linked by beta-glycosidic bonds, known by their ability to modulate non-specific immune response in mammals. It was approved that beta-glucans stimulate both specific and non-specific immune responses in mammals. The action mechanisms include activation of macrophages, neutroophils and NK cells together with B and T lymphocytes, increasing of phagocytosis and cytokine macrophage production in vivo $[12,13]$.

The objective of this study was to evaluate specific and non-specific immune responses of weaned piglets vaccinated against Lawsonia intracellularis after feeding their dams with the immunomodulating remedy containing beta-glucan for 48 days.

\section{MATERIALS AND METHODS}

\section{Animals and experimental design}

In the experiment, thirty-five suckling piglets from four crossbred sows (Slovak white, Landrace) were used. The sows were divided into 2 groups: control $(n=2)$ and experimental $(n=2)$. Control sows were fed standard feed mixtures for pregnant and lactating sows only. Experimental sows were given feed additive containing beta-glucan (IMUNOL P, Polychem spol. s.r.o., Slovakia) at 5\% concentration from the 21 st day before farrowing up to weaning. The composition of the additive is presented in Table 
1. The sows were regularly monitored from one month before the experiment up to weaning. The suckling piglets were divided into four groups (A, B, C, D) according to dams feeding regimen with beta glucan $(C, D)$ and according to vaccination $(B, C)$ against Lawsonia intracellularis (Enterisol ${ }^{\circledR}$ Ileitis, Boehringer Ingelheim Gmbh, Germany) (Table 2). This vaccine contains a live attenuated $L$. intracellularis isolate (min. $1 \times 10^{4,9}$, max. $\left.1 \times 10^{6,1} \mathrm{TCID}_{50}\right)$. Oral vaccination of suckling piglets was done at the time of weaning (at 28th day of life) with subsequent re-vaccination at 56th day of life. Pigs received the appropriate vaccine dose orally, according to the manufacturer's instruction in $2.0 \mathrm{ml}$ diluent by drenching gun.

Table 1. Composition of dietary additive IMUNOL P

\begin{tabular}{|c|c|}
\hline Compound & content ( $\%$ weight) \\
\hline Beta-1,3/1,6-D-glucan & 0.8 \\
\hline Zeolite & 38.8 \\
\hline Glycerol & 34.0 \\
\hline Silica oxide & 16.7 \\
\hline Water & 9.6 \\
\hline $\mathrm{NaCl}_{3}$ & 9.0 \\
\hline Cholinchloride & $4.5 .10^{-3}$ \\
\hline DL-methionine & $0.9 .10^{-3}$ \\
\hline $\mathrm{ZnCl}_{2}$ & $0.8 .10^{-3}$ \\
\hline E-vitamin (alpha tocopherol $100 \%$ weight) & $8.9 .10^{-5}$ \\
\hline Beta carotene & $3.8 .10^{-5}$ \\
\hline $\mathrm{CoCl}_{2} \cdot 6 \mathrm{H}_{2} \mathrm{O}$ & $1.8 .10^{-5}$ \\
\hline $\mathrm{B}_{3}$-vitamin (niacin $\left.100 \%\right)$ & $1.6 .10^{-5}$ \\
\hline KI & $0.6 .10^{-5}$ \\
\hline $\mathrm{Na}_{2} \mathrm{SeO}_{3} \cdot 5 \mathrm{H}_{2} \mathrm{O}$ & $0.4 .10^{-5}$ \\
\hline
\end{tabular}

Table 2. Experimental groups of pigs

\begin{tabular}{cccccc}
\hline & $\mathbf{n}$ & Feeding & piglets & $\mathbf{n}$ & vaccination \\
\hline Control & 2 & $\begin{array}{c}\text { Standard } \\
\text { feedstuff }\end{array}$ & $\mathrm{A}$ & 7 & - \\
\cline { 3 - 6 } & & $\mathrm{B}$ & 6 & + \\
\cline { 3 - 6 } $\begin{array}{c}\text { Experimental } \\
\text { sows }\end{array}$ & 2 & $\begin{array}{c}\text { Standard } \\
\text { feedstuf } \\
++ \\
\text { Imunol P }\end{array}$ & $\mathrm{C}$ & 12 & + \\
\hline
\end{tabular}

Blood samples in suckling piglets were collected by venepuncture from plexus venosus suborbitalis every week, i.e. on 0 (birth), 7, 14, 21, 28, 35, 42, 49, 56, and 63 days after birth. During the experiment 350 samples of blood sera samples were taken. The blood samples were analyzed for selected indices of immune profile (total immunoglobulins $\mathrm{TIg}$, index of metabolic activity of phagocytes - IMA, and index of stimulation activity of lymphocytes - SI); and post-vaccination antibodies against Lawsonia. Weight gains were checked individually at the same time intervals as blood samplings.

The experiment was done at the Clinical Department for Swine in University of Veterinary Medicine and Pharmacy in Košice, meeting all ethics requirements. 


\section{Estimation of phagocyte activity and total immunoglobulins}

After leukocyte isolation from the peripheral blood [14], we analyzed the index of metabolic activity of phagocytes (IMA) by iodine-nitro-tetrasolium reductase test [15]; stimulation index of lymphocytes (SI) by commercial test kits (Cell Proliferation ELISA Kit, BrdU-colorimetric, Roche) with ELISA reader [16]; and total immunoglobulins (TIg) by turbidimetric spectrophotometric zinc-sulphate test [17].

\section{Detection of specific antibodies against Lawsonia intracellularis}

Commercial kit „bioScreen Ileitis Antibody ELISA“(SYNBIOTICS EUROPE SAS) based on the so-called blocking ELISA was used according to the manufacturer's instruction. The results were read on automatic photometer for microtiter plates Opsys MR (Dynex Technologies) at wavelength $450 \mathrm{~nm}$.

\section{Statistics}

The results are expressed as means and standard deviations. Significance of differences was evaluated by paired Student's t-test and one-way ANOVA (Tukey's multiple comparison test; GraphPad Prism 5).

\section{RESULTS}

The initial levels of specific antibodies (PI) before vaccination (day 0) in all the groups of suckling piglets were very low. The same was observed after four weeks in the nonvaccinates groups (A and D). In the vaccinated groups (B and $C$ ), the levels of specific antibodies were markedly over the level indicating positivity (PI over 30), when the levels in group B were insignificantly higher than in group C (Table 3).

Table 3. Average levels of specific antibodies (PI) against Lawsonia intracellularis in the blood serum of suckling piglets

\begin{tabular}{ccc}
\hline \multirow{2}{*}{ Groups } & \multicolumn{2}{c}{ Day of sampling } \\
\cline { 2 - 3 } & $\mathbf{0}$ & $\mathbf{2 8}$ \\
\hline A & $-13.11 \pm 5.28$ & $-10.96 \pm 7.21$ \\
B & $-0.07 \pm 4.33$ & $79.41 \pm 2.14$ \\
C & $-3.33 \pm 8.29$ & $71.91 \pm 9.05$ \\
D & $4.39 \pm 12.29$ & $8.77 \pm 10.39$ \\
\hline
\end{tabular}

Evaluation of selected indices of immune profile (TIg, IMA, SI) in groups of weanlings $\mathrm{A}-\mathrm{D}$ is presented in tables 4 and 5 .

Average concentration of TIg in all groups showed a double-phase curve characterized by a continuous increase from the $7^{\text {th }}$ up to the $21^{\text {st }}$ day after the birth; followed by a slight decrease up to the day of weaning $\left(28^{\text {th }}\right.$ day), when the highest concentrations were recorded in vaccinated piglets from sows fed beta-glucan (B and C). Similarly, a continuously increasing tendency was observed in the next period after vaccination $\left(28^{\text {th }}\right.$ day) up to the end of the observation period. During this period, the most balanced tendency was recorded in both groups from sows fed beta-glucan, as well as in both 
vaccinated groups compared with the group without any treatment (no vaccination, no beta-glucan), which showed the lowest concentrations.

Table 4. Average blood serum levels of total immunoglobulins $(20-35$ UZST) in suckling piglets

\begin{tabular}{cccccccc}
\hline \multirow{2}{*}{ Groups s } & $\mathbf{7}$ Day of sampling \\
\cline { 2 - 8 } & $\mathbf{0}$ & $\mathbf{7}$ & $\mathbf{1 4}$ & $\mathbf{2 1}$ & $\mathbf{2 8}$ & $\mathbf{3 5}$ & $\mathbf{4 2}$ \\
\hline A & $19.28 \pm 1.77$ & $19.23 \pm 1.09$ & $23.05 \pm 1.50$ & $20.48 \pm 3.73$ & $21.08 \pm 3.57$ & $19.51 \pm 2.16$ & $22.94 \pm 1.60$ \\
B & $18.84 \pm 0.68$ & $24.96 \pm 2.08$ & $28.46 \pm 1.87$ & $24.33 \pm 3.40$ & $22.19 \pm 1.26$ & $24.61 \pm 2.09$ & $29.99 \pm 2.18$ \\
C & $20.54 \pm 4.11$ & $20.02 \pm 3.68$ & $25.18 \pm 2.24$ & $24.47 \pm 1.93$ & $27.22 \pm 1.31$ & $27.29 \pm 2.60$ & $24.14 \pm 4.05$ \\
D & $21.86 \pm 4.33$ & $22.04 \pm 2.16$ & $23.96 \pm 3.13$ & $23.77 \pm 2.64$ & $24.03 \pm 1.95$ & $26.10 \pm 2.08$ & $21.65 \pm 3.06$ \\
\hline
\end{tabular}

In group A (non-vaccinated suckling piglets from sows fed without beta-glucan) a continuous statistically significant decrease $(p<0.01)$ in average IMA values from the $35^{\text {th }}$ to the $63^{\text {rd }}$ day after the weaning was recorded (Table 5). In the other groups (with beta-glucan, as well as after vaccination), the average IMA values showed an increasing tendency with highest values in vaccinated suckling piglets from sows fed beta-glucan (group C).

The highest average stimulation index (SI) was observed in group B three weeks after vaccination (49 ${ }^{\text {th }}$ day). A gradual increase in SI values was recorded also in group D and, at the end of the experiment ( $63^{\text {rd }}$ day), the highest SI value was recorded in nonvaccinated suckling piglets from sows receiving beta-glucan (Table 5).

Table 5. Average values of the index of metabolic activity of phagocytes (IMA) and stimulation index of lymphocytes (SI) in the blood of suckling piglets

\begin{tabular}{rccccc}
\hline \multirow{2}{*}{$\begin{array}{c}\text { Day of } \\
\text { sampling }\end{array}$} & $\mathbf{A}$ & \multicolumn{3}{c}{ Groups } \\
\cline { 2 - 5 } 28 & IMA & $2.74 \pm 0.26$ & $2.88 \pm 0.26$ & $2.99 \pm 0.32$ & $\mathbf{D}$ \\
\hline \multirow{2}{*}{35} & SI & $3.56 \pm 0.29$ & $3.54 \pm 0.26$ & $3.68 \pm 0.34$ & $3.76 \pm 0.29$ \\
& IMA & $2.79 \pm 0.46$ & $2.94 \pm 0.25$ & $3.17 \pm 0.32$ & $2.86 \pm 0.35$ \\
42 & SI & $3.68 \pm 0.39$ & $3.93 \pm 0.35$ & $3.84 \pm 0.36$ & $3.83 \pm 0.38$ \\
& IMA & $2.68 \pm 0.36$ & $2.97 \pm 0.28$ & $3.12 \pm 0.33$ & $2.75 \pm 0.27$ \\
49 & SI & $3.63 \pm 0.27$ & $3.88 \pm 0.29$ & $3.77 \pm 0.36$ & $3.84 \pm 0.36$ \\
& IMA & $2.54 \pm 0.34^{\mathrm{b}}$ & $3.03 \pm 0.28$ & $3.06 \pm 0.28$ & $2.82 \pm 0.40$ \\
56 & SI & $3.86 \pm 0.30$ & $4.07 \pm 0.41$ & $3.76 \pm 0.33$ & $3.94 \pm 0.26$ \\
& IMA & $2.59 \pm 0.39$ & $2.98 \pm 0.35$ & $3.05 \pm 0.28$ & $2.85 \pm 0.28$ \\
63 & SI & $3.69 \pm 0.30$ & $3.89 \pm 0.48$ & $3.74 \pm 0.36$ & $3.97 \pm 0.38$ \\
& IMA & $2.47 \pm 0.37^{\mathrm{b}}$ & $2.88 \pm 0.40$ & $2.95 \pm 0.32$ & $2.74 \pm 0.24$ \\
\hline
\end{tabular}


Average birth body weight in all groups was similar, even though insignificantly lower in the group C. When evaluating average daily weight gain (Table 6), this was quite even considering the variance of minimum and maximum values. Despite this, after weaning and vaccination, significantly higher $(\mathrm{p}<0.01)$ average weight gains were recorded in both vaccinated groups $(\mathrm{B}, \mathrm{C})$, as well as in non-vaccinated suckling piglets from sows fed beta-glucan (D) when compared with control group of suckling piglets (A).

Table 6. Average daily weight gain $(\mathrm{kg})$ in suckling piglets

\begin{tabular}{ccccccc}
\hline \multirow{2}{*}{ Groups } & \multicolumn{7}{c}{ Day of sampling } \\
\cline { 2 - 7 } & $\mathbf{7}$ & $\mathbf{1 4}$ & $\mathbf{2 1}$ & $\mathbf{2 8}$ & $\mathbf{3 5}$ & $\mathbf{4 2}$ \\
\hline $\mathrm{A}$ & $0.17 \pm 0.03$ & $0.27 \pm 0.08$ & $0.20 \pm 0.04$ & $0.25 \pm 0.09$ & $0.36 \pm 0.05$ & $0.21 \pm 0.04$ \\
$\mathrm{~B}$ & $0.27 \pm 0.07$ & $0.31 \pm 0.08$ & $0.36 \pm 0.09$ & $0.33 \pm 0.09$ & $0.23 \pm 0.15$ & $0.58 \pm 0.13^{\mathrm{b}}$ \\
$\mathrm{C}$ & $0.17 \pm 0.06$ & $0.22 \pm 0.06$ & $0.14 \pm 0.07$ & $0.29 \pm 0.07$ & $0.23 \pm 0.12$ & $0.44 \pm 0.10^{\mathrm{b}}$ \\
$\mathrm{D}$ & $0.14 \pm 0.03$ & $0.24 \pm 0.04$ & $0.18 \pm 0.07$ & $0.19 \pm 0.06$ & $0.26 \pm 0.09$ & $0.41 \pm 0.12$ \\
\hline${ }^{\mathrm{b}} \mathrm{p}<0.01$ & & & & & &
\end{tabular}

\section{DISCUSSION}

Health of farm animals (including pigs) is one of the major factors underlying the economy of animal production and farm profit. Excessive stress caused by early weaning, as well as sudden change of diet leads to disturbances in the immune system followed by occurrence of various diseases.

According to the producer, during vaccination with Enterisol ${ }^{\circledR}$ Ileitis, there is a gradual reaction of body and maximum level of antibodies during 14-21 days after vaccination. However this was not demonstrated in our experiment according to findings of Kroll, Roof and McOrist [18], who refer that protection after immunization gets on at latest after three weeks after application of the preparation and lasts for $17-22$ weeks.

The timing and duration of humoral responses is also well studied and relatively consistent. In the study of Noqueira et al. [8], a 10x dose oral vaccination elicited increased levels of $\operatorname{IgM}, \operatorname{IgG}$ in the blood serum and ileal mucosal scrapings. Attenuated live vaccine provides active immunity against the damages caused by Lawsonia intracellularis infection, improves weight gain, protects against diarrhea and mortality associated with ileitis, and offers long lasting immunity instead of the need for a continuous use of antibiotics $[7,8]$.

In present, as an alternative for increased production, it appears to be possible to use various natural-based matters with beneficial effects on the immune system increasing thus the resistance to infections of various origin. From this point of view, the feed admixture containing beta-glucan used in our experiment meets all the criteria $[19,20]$. It is generally known that beta-glucans, as matters of natural origin, have potential immune-modulating effects [21]. Their bond to specific receptors stimulates the activity of phagocytes and triggers signal cascades leading to expression of cytokines and chemokine genes, which was confirmed in piglets in several in vivo and in vitro studies $[18,22,23]$. 
Besides reported higher weight gain, there are also reports of their stimulating effect on increased resistance of suckling piglets against infectious agents, their influence on phagocytic activity of cells and production of reactive forms of oxygen, proliferative activity of lymphocytes, and expression of specific receptors [24,25].

With this aim, we performed the experiment on weaned piglets, where after immune-modulation of sows and expectation of higher trans-colostral transfer of immunoglobulins, a higher production of specific antibodies after oral vaccination of weaned piglets was expected.

Although in vaccinated piglets we recorded higher levels of specific antibodies compared with both positive and negative controls, we did not record significant differences between vaccinated groups.

Immunostimulating effects of the feed admixture containing beta-glucan were manifested by changes in selected blood serum indices of the immune profile. During the experiment, total immunoglobulins (TIg) showed a biphasic course, when in all the groups at weaning we recorded their innate decrease with a subsequent increase, which was significantly higher in vaccinated and beta-glucan stimulated piglets. Indices of functional leukocyte activity (IMA and SI) showed the positive immunostimulation in both vaccinated and beta-glucan stimulated animals.

Because of the small number of experimental sows, beneficial effects of the feed admixture on sows production indices (live-born, dead-born or died piglets) (Table 7) should be verified with a field-trial However, the experiment was targeted to piglets, which numbers are sufficient to evaluate the results objectively.

Table 7. Average values of birth weight $(\mathrm{kg})$, total number, number of live- and dead-born and died piglets

\begin{tabular}{ccccccc}
\hline & & \multicolumn{5}{c}{ Number of piglets } \\
\cline { 3 - 7 } Group & $\mathbf{n}$ & total & Live-born & Dead-born & died & Birth weight \\
\hline $\mathrm{A}$ & 7 & 9 & 9 & 0 & 2 & $1.65 \pm 0.363$ \\
$\mathrm{~B}$ & 6 & 8 & 6 & 2 & 0 & $1.67 \pm 0.266$ \\
$\mathrm{C}$ & 12 & 13 & 12 & 1 & 0 & $1.56 \pm 0.171$ \\
$\mathrm{D}$ & 10 & 11 & 11 & 0 & 1 & $1.76 \pm 0.135$ \\
\hline
\end{tabular}

In general, the effectiveness of immunization depends on the way and time of vaccine administration. Requirements for potentiating general or local immunity, or antibody and cell mediated immunity, as well as the time of immunization depend on disease pathogenesis. Most of vaccines are administered repeatedly to induce a strong immune response; however, it is important to use the adequate re-vaccination interval [26].

The oral live attenuated vaccine was produced in abeyance with pathogenesis of the causative agent. From the two possible ways of administration (drinking water, drenching) we have chosen drenching as a more accurate procedure [27]. Vaccine use in drinking water is suitable for mass administration; however, it demands adjustment of water quality (chlorine) and monitoring of water consumption [7]. Anyway, there is an uncertainty of vaccine intake in all the animals. Within the experiment, we respected 
also the rule regarding the achievement of an efficient and long-lasting immunity by revaccination at the recommended interval of $2-4$ weeks between vaccinations.

In our way of vaccination we found quite negative levels of detergent specific antibodies in all the groups of suckling piglets at the time of weaning before vaccination. Another favorable finding was recorded in the group of suckling piglets vaccinated at the age of 28 days. After vaccination, in these piglets we achieved a sufficiently high positive level of specific antibodies, despite the fact that at this age there is a theoretical and practical assumption of an immature immune system. Compared with the control group A (without vaccination and immunostimulation), another promising fact is the finding of increased weight gain in both vaccinated groups of sucklings, as well as in beta-glucan stimulated groups after the weaning (42 days).

The favorable findings in our experiment should be verified with a set of field-trials.

\section{ACKNOWLEDGEMENT}

This work was supported by the Ministry of Education of the Slovak Republic (research project VEGA No 1/0537/12 and KEGA No 007UVLF-4/2012).

\section{REFERENCES}

1. Lawson GHK, Gebhart CJ: Proliferative Enteropathy. J Comp Pathol 2000, 122: 77-100.

2. Soročinová J, Kovačocyová K, Smaržik M, Reichel P: Results of determination of antibodies against Lawsonia intracellularis by ELISA method in selected swine farms in Slovakia. Infovet 2011, 4: 160-161.

3. Gebhart CJ, Barns SM, McOrist S, Lin GF, Lawson GHK: Ileal symbiont intracellularis, an obligate intracellular bacterium of porcine intestines showing a relationship to Desulfovibrio species. Int J Syst Bacteriol 1993, 43: 533-538.

4. McOrist S, Jasni S, Mackie RA, MacIntyre N, Neef N, Lawson GHK: Reproduction of Porcine Proliferative Enteropathy with Pure Cultures Of Ileal Symbiont Intracellularis. Infect Immun 1993, 61(10): 4286-4292.

5. McOrist S, Gebhart CJ, Boid R, Barns SM: Characterization of Lawsonia intracellularis gen. nov., sp. nov., the obligately intracellular bacterium of porcine proliferative enteropathy. Int J Syst Bacteriol 1995, 45(4): 820-825.

6. Jacobson M, Fellström C, Jensen-Waern M: Porcine proliferative enteropathy: An important disease with questions remaining to be solved. Vet J 2010, 184: 264-268.

7. McOrist S, Hardge T, Gebhart C, Ohlinger V, Pohlenz J, Keller Ch, Voets H, Walter D: Porcine Proliferative Enteropathy Technical Manual 3.0 2006: 7-156.

8. Nogueira MG, Collins AM, Donahoo M, Emery D: Immunological responses to vaccination following experimental Lawsonia intracellularis virulent challenge in pigs. Vet Microbiol 2013, 164: 131-138.

9. Hardge T, Nickoll E, Grunert H, Elbers K, Langbein U, Keller C, Bleier T, Pohlenz J, Ohlinger VF, Schroeder B: Prevention of porcine proliferative enteropathy (PPE) by vaccination - efficacy and economics in European farms. Pig J 2004, 54: 17-34.

10. Smola J, Dezorzová K: Proliferativní enteropatie (PE) prasat a Lawsonia intracellularis - první desetiletí našich zkušeností. Veterinářství 2007, 2: 92-98. 
11. Chovancová A, Šturdík E: Vplyv beta-glukánov na imunitný systém človeka. Nova Biotechnologica 2005, V-I: 105-121.

12. Zhou TX, Jung JH, Zhang ZF, Kim IH: Effect of dietary ß-glucan on growth performance, fecal microbial shedding and immunological responses after lipopolysccharide challenge in weaned pigs. Anim Feed Sci Tech 2013, 179: 85-92.

13. Haladová E, Mojžišová J, Smrčo P, Ondrejková A, Vojtek B, Prokeš M, Petrovová E: Immunomodulatory effect of glucan on specific and nonspecific immunity after vaccination in puppies. Acta Vet Hung 2011, 59 (1): 77-86.

14. Karlson GP, Kaneko JP: Isolation of leukocytes from bovine peripheral blood. Proc Soc Exp Biol Med 1973, 142: 853-856.

15. Lokaj V, Oburková P: Determination of tetrazolium-reductase activity of leukocyte. Imunol Zprav 1975, 6: 42-44.

16. Pistl J, Kovalkovičová N, Holovská V, Legáth J, Mikula I: Determination of the immunotoxic potential of pesticides on functional activity of sheep leukocytes in vitro. Toxicology 2003, 188: 73-81.

17. Slanina L, Vajda V, Blažej J: Turbidimetric analysis of immunoglobulins in calves and their clinical evaluation. Veterinářství 1976, 9: 392-394.

18. Kroll JJ, Roof MB, McOrist S: Evaluation of protective immunity in pigs following oral administration of an avirulent live vaccine of Lawsonia intracellularis. Am J Vet Res 2004, 65(5): 559-565.

19. Kogan G: 1,3/1,6- $\beta$-D-glucans of yeasts and fungi and their biological activity. Studies in Nat Prod Chem 2000, 23: 107-152.

20. Volman JJ, Ramakers JD, Plat J: Dietary modulation of immune function by $\beta$-glucans. Physiol Behav 2008, 94(2): 276-284.

21. Eicher SD, McKee CA, Carroll JA, Pajor EA: Suplemental vitamin C and yeast cell wall $\beta$-glucan as growth enhancers in newborn pigs and as immunomodulators after an endotoxin challenge after weaning. J Anim SCI 2006, 84: 2352-2360.

22. Míčková K, Blafková P, Černá J, Čopíková J, Synytsya An, Synytsya Al, Spěváček J, Jablonský I, Erban V: Studium $\beta$-glukanů izolovaných z Pleurotus sp. a Agaricus sp. Chem listy 2005, 99: 661-671.

23. Hurnik D, Lank T, Spencer P, Patelakis S: The immunomodulary effects of yeast beta glukan on pregnant and lactation sows [abstract]. Proceedings of the 19th IPVS Congress, Copenhagen, Denmark 2006: 649.

24. Hiss BS, Saurwein H: Influence of dietary $\beta$-glukan on growth performance, lymphocyte proliferation, specific immune response and haptoglobin plasma concentrations in pigs. J Anim Physiol a Anim Nutr 2003, 87. 2-11.

25. Hahn TW, Lohakare JD, Lee SL, Moon WK, Chae BJ: Effects of supplementation of $\beta$-glucans on growth performance, nutrient digestibility, and immunity in weanling pigs. J Anim Sci 2006, 84: 1422-1428.

26. Toman M, Trebichavský I: Imunológie plodu a novorozence, In: Veterinární imunologie. Praha, Czech Republic: GRADA Publishing; 2000, 144-152.

27. Voets $H$, Hardge T: Increasing carcass uniformity by use of Enterisol ${ }^{\mathbb{R}}$ Ileitis immunization. Proceedings of Annual Meeting of the American Association of Swine Veterinarians 2007, 38: 289-294. 


\title{
UTICAJ BETA-GLUKANA I VAKCINACIJE PROTIV LAWSONIA INTRACELLULARIS NA ODABRANE IMUNSKE PARAMETRE ODLUČENE PRASADI
}

\author{
KOVAČOCYOVÁ Katarína, REICHEL Peter, SEIDEL Herbert, \\ BRENESSELOVÁ Martina, KÓSA Balász
}

Cilj ispitivanja je bio istraživanje uticaja, odnosno mogućeg imunostimulirajućeg efekta dodatka stočnoj hrani, koji je sadržavao beta-glukan, a prilikom ishrane suprasnih krmača kao i imunomodulirajući uticaj na kasniju vakcinaciju prasadi koja sisaju poreklom od ovih krmača. Trideset i pet prasadi koja sisaju, poreklom od kontrolne i eksperimentalne grupe krmača, podeljeno je u četiri grupe. Odabrani indikatori imunskog profila (Tig, IMA, SI), specifični imunski odgovor na Lawsonia intracellularis koji je određivan u krvnom serumu prasadi koja sisaju, a posle vakcinacije kao i proizvodne karakteristike su posmatrane kod prasadi. U svim grupama prasadi, telesne mase su bile slične odnosno, nisu se razlikovale. Posle zalučenja, prosečni dnevni prirast telesne mase bio je značajno veći $(\mathrm{p}<0,05)$ u grupi vakcinisanih prasadi koja sisaju, kao i kod prasadi koji su poticali od krmača eksperimentalne grupe. Isti je trend uočen i kod vrednosti Tig. Značajan efekat $(p<0,01)$ beta-glukana i vakcinacije je uočen u odnosu na promenu indeksa metaboličkih aktivnosti fagocita (IMA) uz manje naglašen uticaj na indeks stimulacije limfocita (SI). Najslabiji rezultati su uočeni u grupi koja nije bila vakcinisana i bez dodataka beta-glukana u hrani za krmače. Efekat vakcinacije je posmatran pomoću odredivanja specifičnih antitela (ELISA). Uočeno je da je u obe nevakcinisane grupe, koncentracija antitela bila minimalna u poređenju sa vakcinisanim (B i C) grupama. U ovim grupama (B i C) nije bilo značajnih razlika između vakcinisanih grupa koje su stimulisane beta-glukanom (grupa C) i koje nisu stimulisane beta-glukanom (grupa B). $\mathrm{Na}$ ovaj način je prikazano da se davanjem beta-glukana kao dodatka hranivu za suprasne krmače, značajno može da stimulatorno utiče kako na nespecifičan tako i na specifičan imunski odgovor kod prasadi poreklom od ovih krmača. 